\title{
COMPARISON OF THREE SCHOOL FEEDING STRATEGIES FOR PRIMARY SCHOOL CHILDREN IN AN INformal SeTtlement in GAuteng, South Africa
}

\section{Authors:}

Carin Napier ${ }^{1}$

Wilna Oldewage-Theron ${ }^{2}$

Jeanette Kearney ${ }^{3}$

\section{Affiliations:}

${ }^{1}$ Food and Nutrition

Consumer Sciences,

Durban University of

Technology, South Africa

${ }^{2}$ Institute of Sustainable

Livelihoods, Vaal

University of Technology,

South Africa

${ }^{3}$ Department of

Hospitality and Tourism,

Vaal University of

Technology, South Africa

\section{Correspondence to:}

Carin Napier

e-mail:

carinn@dut.ac.za

\section{Postal address:}

Durban University of

Technology, PO Box 953,

Durban, South Africa

\section{Keywords:}

primary school children;

South Africa; school

feeding; nutritional status;

malnutrition

\section{Dates:}

Received: 28 Aug. 2008

Accepted: 27 Apr. 2009

Published: 27 July 2009

How to cite this article:

Napier, C., Oldewage-

Theron, W. \& Kearney, J.,

2009, 'Comparison of three

school feeding strategies

for primary school

children in an informal

settlement in Gauteng,

South Africa', Health SA

Gesondheid 14(1), Art.

\#458, 8 pages. DOI:

10.4102/hsag.v14i1.458

\section{This article is available at:}

http://www.hsag.co.za

\section{(c) 2009. The Authors.}

Licensee: OpenJournals

Publishing. This work

is licensed under the

Creative Commons

Attribution License.

\section{ABSTRACT}

The aim of this study was to compare the impact of three school feeding strategies on the nutritional status of primary school children aged six to 13 in an informal settlement in Gauteng.

The methods included dietary surveys and anthropometric and biochemical measurements of a sample of 160 primary school children allocated to three different school feeding intervention groups. One group $(n=60)$ received a whole wheat pilchard and spinach vetkoek, a second received food according to the Government Primary School Nutrition Programme (PSNP) ( $n=60)$, and a third $(n=40)$ received fruit. The children were given these items every day for seven months, except during school holidays and weekends. The baseline anthropometric measurements indicated that $13.6 \%, 20.9 \%$ and $10.8 \%$ of the children in the vetkoek, PSNP and fruit groups respectively were underweight ( $<5$ th percentile for weight-for-age) and $17.3 \%, 23.6 \%$ and $5.2 \%$ were stunted $(<5$ th percentile for height-for-age).

The post-intervention results indicated that the children in all three groups had improved significantly in weight and height, and in dietary intakes of zinc and iron.

The results of this study indicated that all three feeding strategies contributed to an improved nutritional status. Providing fruit as a school feeding strategy may be the most affordable and easy to implement. More research is recommended to measure the impact of these strategies on a longterm basis.

\section{OPSOMMING}

Die doel van die studie was om die impak van drie skoolvoedingstrategieë op die voedingstatus van ses tot dertien jaar oue laerskoolkinders in ' $n$ informele nedersetting in Gauteng te bepaal.

Die metodes het die volgende ingesluit: dieetopnames, antropometriese en biochemiese metings in 'n steekproef van 160 laerskoolkinders, wat ewekansig in drie skoolvoedingintervensiegroepe verdeel is. Die groepe het bestaan uit 'n volkoring sardyn-en-spinasie-vetkoek groep $(n=60)$, die Government Primary School Nutrition Programme (PSNP) groep (n=60), en 'n vrugtegroep $(n=40)$ wat hierdie items elke dag vir sewe maande, behalwe vir skoolvakansies en naweke, ontvang het. Die antropometriese metings voor die intervensie het bevind dat $13.6 \%, 20.9 \%$ en $10.8 \%$ van die kinders ondergewig (<5de persentiel vir gewig-vir-ouderdom) was in die vetkoek-, PSNP- en vrugtegroep, respektiewelik, en $17.3 \%, 23.6 \%$ en $5.2 \%$ se groei is belemmer $(<5$ de persentiel vir lengte-vir-ouderdom).

Die na-intervensieresultate het aangedui dat die kinders in al drie die groepe se gewig, lengte, sowel as sink en ysterinname betekenisvol verbeter het.

Die resultate van hierdie studie het aangetoon dat al drie die voedingstrategieë bygedra het tot 'n verbeterde voedingstatus. Die voorsiening van vrugte as 'n skoolvoedingstrategie is egter bekostigbaar en maklik om te implementeer. Meer navorsing om die impak op die langtermyn te toets, word aanbeveel.

\section{INTRODUCTION}

Nutrition affects children's ability to learn. The link has been established for some time through controlled research studies (Levitsky 2005:S270). The United Nations Children's Fund (UNICEF 2001) reported that when a child lacks nurturing care or suffers from malnutrition, stress, trauma, abuse or neglect, the growing brain is the first casualty. Malnutrition is caused by various factors and, at its most immediate level, is a consequence of poor food intake as well as infections and disease resulting in nutrient inadequacy. The implications of malnutrition include both growth failure and functional disability (UNICEF 1998; Vorster et al. 1998). Enhancement of children's health and nutrition is thus a world-wide priority and requires immediate attention (UNICEF 1998; Food and Agricultural Organization of the United Nations (FAO) 1998).

Furthermore, the 1999 National Food Consumption Survey (NFCS) indicated that at national level, one out of five children from one to nine years old is stunted (Labadarios 2000:14). Gauteng showed a prevalence of $20 \%$. Nationally, the prevalence of stunting decreased with age, from $25.5 \%$ in children aged one to three years, to $21 \%$ in those aged four to six years, to $13 \%$ in those from seven to nine years old. A similar pattern emerged for the prevalence of underweight children, whilst the prevalence of wasting remained constant at less than $4 \%$ in all age groups (Labadarios 2000:14).

In terms of iron status, $10 \%$ of children in South Africa are iron-depleted, one in 20 (5\%) is severely irondepleted and one in $20(5 \%)$ has iron deficiency anaemia. Anaemia and poor iron status are more prevalent in urban areas, and children in the 6-23 month age group are most adversely affected (South African Vitamin A Consultative Group (SAVACG) 1995). 
An analysis of the data from a number of smaller studies conducted from 1976 to 1996 showed that both iron and folate deficiencies existed in White and many Coloured primary school children, whereas only iron deficiency was found to be a problem in Indian pre-school children. Furthermore, multiple micronutrient deficiencies existed in rural Black pre-school children (vitamin A, iron, folate, vitamin E, vitamin B6) (Vorster et al. 1997). These data thus showed that both stunting and micronutrient deficiencies have continued to be a problem amongst children in South Africa.

This study was undertaken in a primary school in an informal settlement which consists of 1261 Black households and is situated in the Vaal region of South Africa, an industrial, polluted area approximately 70 kilometres south of Johannesburg. The Vaal region has a population of 794599 people, of whom $47.9 \%$ are unemployed, while $46.1 \%$ of the households in this region live in poverty (McIlrath \& Slabbert 2003). This is the only school in this informal settlement. During a cross-sectional baseline survey of 350 of the settlement's households ( $n=357$ caregivers, $\mathrm{n}=149$ children $9-13$ years old) conducted by the researchers in 2004, the results indicated that most of the households were Black (100\%), Sesotho-speaking (68\%), female-headed, singleparent households $(56 \%)$, with an average household size of 4.9 people living in zinc shacks $(90 \%)$. The socio-economic indicators showed an unemployment rate of $94 \%$, and that $58 \%$ of the households had an income below R1000 per month, indicating a level of poverty resulting in household food insecurity (Oldewage-Theron, Dicks \& Napier 2006:796). The results of the baseline survey showed that this community represented the 'poorest of the poor' as the unemployment rate and resulting level of poverty was worse than the rest of the Vaal region as found by McIlrath and Slabbert (2003).

$15 \%$ of the households had an average of three or more children and $92.5 \%$ had a child or children in school. In general, the overall nutrient intake of the children was poor as the majority of the children consumed a diet which, when compared with the Dietary Reference Intakes (DRIs), was deficient in energy, zinc, iron, calcium, vitamin $\mathrm{C}$, vitamin $\mathrm{D}$, vitamin $\mathrm{E}$, selenium, folate, pantothenate, vitamin B6 and niacin (Oldewage-Theron et al. 2006:798). The anthropometric data, when compared with the National Centre for Health Statistics (NCHS) standards, indicated that $20 \%$ of the children were stunted or chronically malnourished, and $28 \%, 25 \%$ and $12 \%$ were under the 5 th percentile for height-for-age, weight-for-age and BMI-forage respectively. The biochemical analysis showed a zinc deficiency (mean serum zinc of $58.5 \pm 9.7 \mathrm{mcg} / \mathrm{dl}$ ), and marginal serum ferritin levels (mean serum ferritin of $24.5 \pm 14.1 \mathrm{mcg} / 1$ ), indicating iron depletion (Napier 2006:170).

In South Africa, the Primary School Nutrition Programme (PSNP) was implemented in 2004 as one of the Presidential Lead projects to alleviate temporary hunger amongst identified vulnerable primary school children, by providing $20 \%$ of the child's daily feeding needs by means of a snack. Criteria for participation in the PSNP are the following:

- $\quad$ Age: The needy child identified must be between the ages of six and 14 .

- Number of dependants in household: the teacher should determine the number of children, elderly persons, disabled and unemployed adults in the household of the identified child.

- Highest qualification of the caregiver, to assess possible earnings.

- Employment status of the caregiver.

- Food support: Any support that the family receives in the procuring of food has to be indicated.

- Income: Calculation of the total income into the household is required, including salary, pension income and disability grant (Gauteng Department of Health (DoH) 1997:4).
At the time of this study only certain children $(25 \%$ of total school population) identified by the teachers according to the guidelines above were included in the PSNP programme in this informal settlement. However, this being a poverty stricken community, the school principal requested that the researchers investigate affordable alternatives which could be implemented as school feeding strategies for the children not eligible for the PSNP.

The purpose of this study was thus to compare two alternative school feeding strategies with the PSNP by measuring the impact of these three strategies on the nutritional status of primary school children aged six to 13 years in this informal settlement.

\section{RESEARCH METHOD} Study population and sampling

The caregivers of 160 children ( $31 \%$ of the children in the school) aged six to 13 gave consent for their children to participate in this study. Thus all the children in the sample had written parental consent and consented to participate in the study. Of these, 60 children were participating in the PSNP and automatically formed the PSNP group. Of the remaining 100 children, 60 were randomly allocated to the vetkoek group and the rest $(n=40)$ to the fruit group. The study was approved by the Medical Ethics Committee for research on human beings at the University of the Witwatersrand (WITS), and pre- and post-intervention data were collected in April and November 2004 respectively. For ethical reasons, all those children in the school who were not participating in this study received a portion of fruit daily for the duration of the study and, as a result, a limitation of this study was the absence of a control group.

Another limitation of this study was that all measurements had to be completed between $06 \mathrm{~h} 00$ and $07 \mathrm{~h} 30$ so that children would not miss classes. Different measurements were thus undertaken on different days. Owing to absenteeism, a complete data set could not be obtained for all the respondents. This is reflected in the variance of sample sizes in the various tables.

\section{Intervention}

A $120 \mathrm{~g}$ whole wheat pilchard fish and spinach vetkoek (deep fried whole wheat yeast cake) was developed specifically for this intervention. In the baseline survey conducted during 2004, it was observed that vetkoek was a popular menu item in this community. Furthermore, all the ingredients were available in the households and after informal discussions with various teachers and caregivers, vetkoek was identified as a suitable food product to be developed for a school feeding programme in this community. To ensure sustainability a food product was chosen that could be prepared by the caregivers on completion of this study. A recipe leaflet was developed and caregivers were trained on the preparation of the vetkoek after the study, but this did not form part of the focus of this paper. The formulation criteria included meeting $25 \%$ of the Estimated Average Requirements (EAR) for children aged six to 13 for energy, iron and zinc (Institute of Medicine (IOM) 2003). The product also consisted of food items readily available in the household and known to the children; it cost R1.51 per child, per day. The product was tested for sensory acceptability and safety through shelf-life testing (Kearney 2006:127).

A $4 \times 4 m^{2}$ kitchen was erected on the school premises for the sole use of the trained community workers in preparing the food on a daily basis. The kitchen consisted of all the equipment needed to prepare the daily products for the requisite number of children. Five community workers, identified by the school, were trained in hygiene and safety as well as food preparation.

The three groups consisted of a randomly selected vetkoek group of 60 , a purposive sample of 60 children participating in the PSNP, and a fruit group with 40 children. The vetkoek, PSNP 
and fruit were distributed daily at first break during the school week to the respective groups of children, and compliance was closely monitored and recorded by the researcher. The fruit group received one type of fruit per day (100 g) depending on availability and season, for example, an apple, orange, banana or pear. The PSNP group received a variety of items as determined by the $\mathrm{DoH}$, including $80 \mathrm{~g}$ of brown bread with either $30 \mathrm{~g}$ of peanut butter or $20 \mathrm{~g}$ of jam sandwiches served with $200 \mathrm{ml}$ of a vitamin C enriched cool drink on Mondays, on Tuesdays $100 \mathrm{~g}$ of fortified biscuits was served with $200 \mathrm{ml}$ of the vitamin C enriched cool drink. The menu on Wednesdays was similar to Mondays, but a $100 \mathrm{ml}$ portion of fresh, full-cream milk replaced the cool drink. On Thursdays pilchard sandwiches consisting of $80 \mathrm{~g}$ of brown bread with $20 \mathrm{~g}$ of margarine and $30 \mathrm{~g}$ of fish were served with $200 \mathrm{ml}$ of the vitamin $C$ enriched cool drink. On Fridays $80 \mathrm{~g}$ of brown bread with $20 \mathrm{~g}$ of margarine and $200 \mathrm{ml}$ of maas were served. No choices were offered on any days.

The researchers visited the school on a daily basis during the first month and thereafter twice a week to monitor the delivery and storage of ingredients as well as the preparation and serving sizes of the vetkoek according to the prescribed recipe. The researchers also monitored the provision of the fruit. The PSNP was managed by the school teachers and although the researchers could not control the provision of the PSNP, the researchers monitored the provision of PSNP to the participants of this study. The children in the three groups consumed their meals in the groups, supervised by the community workers, before being allowed to leave the area. Children were not allowed to share and no wastage was reported.

The children were not allowed to change groups and were checked for attendance on a daily basis for seven months (150 school days), excluding weekends and school holidays. Children were assessed at baseline and then after seven months of the intervention. The measurements chosen for this intervention included a 24-hour recall to measure actual nutrient intake, quantitative food frequency questionnaire (QFFQ) to measure usual intake, anthropometric and biochemical measurements, as well as school attendance records for all three participating groups.

\section{Data enumerators}

Eleven third-year and postgraduate students from the Food and Beverage Management and Food and Consumer Science departments of the Vaal University of Technology were recruited and trained as fieldworkers to assist in the completion of the socio-demographic questionnaires, 24-hour recall questionnaires, QFFQs and anthropometric measurements. Qualified nursing personnel collected blood samples.

\section{Data collection}

Body weight, in light clothing and barefoot, was determined to the nearest $0.1 \mathrm{~kg}$ on two new Philips electronic bathroom scales, model HF350; height was measured with a Scales 2000 portable stadiometer to the nearest $0.5 \mathrm{~cm}$. All measurements were taken twice and the average of the two measurements was recorded.

A socio-demographic questionnaire was completed for each household, data collected were grouped under personal information, accommodation and family resources, work status and income, education and language and assets. Sociodemographic data is an indicator of poverty as well as other social and economic conditions that are important determinants of health (Joubert \& Ehrlich 2008). The information from this questionnaire was used to indicate the socio-economic status of this community that directly influences the food intake of the children in this school. A pre-validated, structured, 24hour recall questionnaire (Oldewage-Theron et al. 2005:17) and a validated QFFQ (MacIntyre 1998) that was adapted for this study were used to obtain dietary intake and food consumption data (pre-intervention). Two 24-hour recalls (post-intervention) were obtained from each child and his or her caregiver during personal interviews, using the same 24-hour recall questionnaire. Food models and cooked porridge samples were used as memory aids and to assist in quantification of portion sizes. All data were encoded with the assistance of a qualified dietician and analysed by the Foodfinder ${ }^{\circledR}$ version 3 computer software. The software was updated to include the new fortified maize meal, which was implemented during the intervention.

As soon as the children arrived at school, a fasting venous blood sample was taken by six registered nursing sisters, wearing disposable polyethylene gloves, free of talc or any other coatings, using a stainless steel Vacutainer needle and with minimal use of tourniquets. The children were served breakfast $(100 \mathrm{ml}$ yoghurt, $200 \mathrm{ml}$ fruit juice and a cheese sandwich [2 slices of brown bread with $30 \mathrm{~g}$ cheese]) immediately after blood collection. Vacutainer blood-collecting tubes were labelled in advance with the subject's trial number as well as the week number.

Blood samples were collected as follows:

- Five $\mathrm{ml}$ of blood in Ethylenediaminetetraacetic acid (EDTA) tubes (purple lid) for full blood counts, haemoglobin $(\mathrm{Hb})$, haematocrit (Hct), red blood cell count (RBC), mean cell volume (MCV) and white cell count (WBC).

- Five $\mathrm{ml}$ of blood in silicone-coated tubes for the preparation of serum for the analysis of serum iron, ferritin, transferrin, total protein and albumin.

- Five $\mathrm{ml}$ of blood in silicone-coated tubes for preparation of serum for the analysis of serum vitamin A and zinc. It has been reported that prolonged use of tourniquets may result in an increase in serum or plasma zinc levels; hence they should be used for about one minute only. Blood was drawn into trace element-free evacuated tubes without anticoagulant using siliconised stoppers (Gibson 2005).

- Two medical technologists were responsible for handling the blood according to standard protocol and audited the blood analysis. The blood was placed on ice until separation within two hours, and separated (centrifuged at $1.500 \mathrm{Xg}$ for 20 minutes) plasma and serum were aliquoted in marked Eppendorf test tubes. All blood parameters were analysed according to standard protocol and all the equipment used (excluding the disposable items) was decontaminated before use. Serum for zinc and vitamin A analysis was covered with aluminium foil and stored at $-10^{\circ} \mathrm{C}$ until it was couriered to the Nutritional Intervention Research Unit of the Medical Research Council (MRC) in Cape Town. Serum zinc was determined by the atomic absorption spectroscopy (AAS) method and vitamin A by high performance liquid chromatography (HPLC).

- Serum for the analysis of the remaining parameters was stored at $-10^{\circ} \mathrm{C}$ until analysis. The EDTA tubes were placed directly on a sample tube mixer for immediate analyses. The following analyses were performed: haematocrit (Hct) (numeric integration, [Coulter counter $\mathrm{ABX} \mathrm{MICROS}_{\mathrm{CT}}$ ); haemoglobin $(\mathrm{Hb})$ (cyanmethaemoglobin colorimetric method [Coulter counter ABX MICROS ]); white blood cell count (WBC); mean cell volume (MCV); red blood cell count (RBC) (Coulter counter ABX MICROS ${ }_{\mathrm{CT}}$ ); serum albumin (colorimetric [Konelab $\left.{ }^{\mathrm{TM}}, \mathrm{BCG}\right]$ ) and total protein (colorimetric [Konelab $\left.{ }^{\mathrm{TM}}\right]$ ); iron (colorimetric [RocheUnimate 5 Iron]); ferritin (immunoturbidometric method [Roche Unimate 3 FERR]); and transferrin (immunoprecipitation, Konelab $^{\mathrm{TM}}$ ).

A school register was completed on a daily basis to reflect absenteeism over the intervention period.

\section{Data analysis}

Anthropometric data were analysed separately for boys and girls. Weight-for-age, height-for-age and BMI-for-age were evaluated for each child according to the NCHS growth charts. The information was used to indicate underweight, stunting 
TABLE 1

Baseline measurements of participants lost to follow-up compared to participants (Mahan and Escott-Stump 2007)

\begin{tabular}{llll}
\hline VARIABLE & RANGE & $\begin{array}{l}\text { PARTICIPANTS } \\
\text { N= 131 }\end{array}$ & $\begin{array}{l}\text { LOST TO } \\
\text { FOLLOW- UP } \\
\text { N=29 }\end{array}$ \\
\hline & Normal range & Mean (SD) & Mean (SD) \\
\hline Vitamin A & $30-80 \mu \mathrm{g} / \mathrm{dl}$ & $31(19.95)$ & $30.63(9.7)$ \\
Zinc & $70-150 \mu \mathrm{g} / \mathrm{dl}$ & $86.14(12.56)$ & $83.74(12.56)$ \\
Total protein & $64-83 \mathrm{~g} / \mathrm{l}$ & $74.21(12.19)$ & $75.04(7.93)$ \\
Iron & $9-31 \mu \mathrm{mol} / \mathrm{l}$ & $30.51(19.48)$ & $33.36(22.69)$ \\
Transferrin & $2-4 \mathrm{~g} / \mathrm{l}$ & $3.13(0.59)$ & $3.04(0.49)$ \\
Ferritin & $12-200 \mu \mathrm{g} / \mathrm{l}$ & $30.10(18.21)$ & $29.58(15.67)$ \\
Albumin & $35-50 \mathrm{~g} / \mathrm{l}$ & $43.46(6.37)$ & $42.48(5.28)$ \\
Red blood cell count & $4.0-5.4 \times 106 / \mu l$ & $4.62(0.46)$ & $4.63(0.42)$ \\
Haemoglobin & $12.0-14.0 \mathrm{~g} / \mathrm{dl}$ & $13.35(0.81)$ & $13.20(0.93)$ \\
Haematocrit & $36.0-44.0 \%$ & $39.61(3.61)$ & $39.52(2.97)$ \\
Mean red cell volume & $77-91 \mathrm{fl}$ & $85.91(3.97)$ & $85.51(3.91)$ \\
White cell count & $4.5-13.5$ & $6.74(2.32)$ & $6.54(1.7)$ \\
\hline
\end{tabular}

TABLE 2

Comparison of the weight-for-age of the primary school children, pre- and postintervention

\begin{tabular}{|c|c|c|c|c|}
\hline \multicolumn{5}{|l|}{ VETKOEK } \\
\hline Weight-for- & Boys $n=22$ & $n=19$ & Girls $n=37$ & $n=30$ \\
\hline $\begin{array}{l}\text { age } \\
\text { Underweight }\end{array}$ & $\begin{array}{l}\% \text { Pre- } \\
\text { intervention }\end{array}$ & $\begin{array}{l}\% \text { Post- } \\
\text { intervention }\end{array}$ & $\begin{array}{l}\% \text { Pre- } \\
\text { intervention }\end{array}$ & $\begin{array}{l}\% \text { Post- } \\
\text { intervention }\end{array}$ \\
\hline$\leq 5^{\text {th }}$ & 13.6 & 15.8 & 13.5 & 13.3 \\
\hline$>5^{\text {th }}$ and $<25^{\text {th }}$ & 40.9 & 42.1 & 35.2 & 33.4 \\
\hline$\geq 25^{\text {th }}$ and $\leq 75^{\text {th }}$ & 40.9 & 31.6 & 40.5 & 40 \\
\hline$>75^{\text {th }}$ and $<95^{\text {th }}$ & 4.6 & 10.5 & 10.8 & 13.3 \\
\hline$\geq 95^{\text {th }}$ & 0 & 0 & 0 & 0 \\
\hline \multicolumn{5}{|l|}{ PSNP } \\
\hline \multirow{2}{*}{$\begin{array}{l}\text { Weight-for- } \\
\text { age }\end{array}$} & Boys $n=27$ & $\mathrm{n}=20$ & Girls $n=32$ & $n=21$ \\
\hline & $\begin{array}{l}\% \text { Pre- } \\
\text { intervention }\end{array}$ & $\begin{array}{l}\% \text { Post- } \\
\text { intervention }\end{array}$ & $\begin{array}{l}\% \text { Pre- } \\
\text { intervention }\end{array}$ & $\begin{array}{l}\% \text { Post- } \\
\text { intervention }\end{array}$ \\
\hline$\leq 5^{\text {th }}$ & 7.4 & 10 & 34.4 & 38.1 \\
\hline$>5^{\text {th }}$ and $<25^{\text {th }}$ & 48.2 & 40 & 31.2 & 19.1 \\
\hline$\geq 25^{\text {th }}$ and $\leq 75^{\text {th }}$ & 40.7 & 45 & 28.1 & 33.3 \\
\hline$>75^{\text {th }}$ and $<95^{\text {th }}$ & 3.7 & 5 & 6.3 & 9.5 \\
\hline$\geq 95^{\text {th }}$ & 0 & 0 & 0 & 0 \\
\hline \multicolumn{5}{|l|}{ FRUIT } \\
\hline \multirow{2}{*}{$\begin{array}{l}\text { Weight-for- } \\
\text { age }\end{array}$} & Boys $n=21$ & $n=9$ & Girls $n=18$ & $n=13$ \\
\hline & $\begin{array}{l}\% \text { Pre- } \\
\text { intervention }\end{array}$ & $\begin{array}{l}\% \text { Post- } \\
\text { intervention }\end{array}$ & $\begin{array}{l}\% \text { Pre- } \\
\text { intervention }\end{array}$ & $\begin{array}{l}\% \text { Post- } \\
\text { intervention }\end{array}$ \\
\hline$\leq 5^{\text {th }}$ & 4.8 & 0 & 16.7 & 7.6 \\
\hline$>5^{\text {th }}$ and $<25^{\text {th }}$ & 23.8 & 0 & 5.6 & 15.4 \\
\hline$\geq 25^{\text {th }}$ and $\leq 75^{\text {th }}$ & 52.4 & 88.9 & 50 & 23.1 \\
\hline$>75^{\text {th }}$ and $<95^{\text {th }}$ & 19 & 11.1 & 22.2 & 46.2 \\
\hline$\geq 95^{\text {th }}$ & 0 & 0 & 5.6 & 7.7 \\
\hline
\end{tabular}

and wasting at the following cut-off points: $\leq 5$ th percentile indicating severely malnourished children, $>5$ th and $<25$ th percentile indicating children at risk of being malnourished, and $\geq 25$ th and $\leq 75$ th $/ 85$ th percentile being normal. Higher than the 75th / 85th and $<95$ th percentile indicates children at risk of being overweight and $\geq 95$ th percentile indicates overweight.

The nutritional intake data for each group (boys and girls combined) were captured and related in tables and graphs for interpretation. The minimum, mean and maximum intakes of the children were analysed and compared to $100 \%$ of the EAR. Means and standard deviations (SD) of the biochemical measurements were calculated for the total groups. Pearson correlations were conducted in order to determine the association between dietary intake and blood levels for iron, haemoglobin, haematocrit, protein, zinc and transferrin. The differences between vetkoek, PSNP and fruit were determined (post-test minus pre-test) and analysis of variance (ANOVA) as well as post hoc tests (Bonferroni) were carried out to measure statistical significance $(\mathrm{p} \leq 0.05)$ between the groups.
TABLE 3

Comparison of the height-for-age of the primary school children, pre- and postintervention

\begin{tabular}{|c|c|c|c|c|}
\hline \multicolumn{5}{|l|}{ VETKOEK } \\
\hline Height-for- & Boys $n=22$ & $n=19$ & Girls $n=37$ & $n=30$ \\
\hline Stunting & $\begin{array}{l}\% \text { Pre- } \\
\text { intervention }\end{array}$ & $\begin{array}{l}\% \text { Post- } \\
\text { intervention }\end{array}$ & $\begin{array}{l}\% \text { Pre- } \\
\text { intervention }\end{array}$ & $\begin{array}{l}\% \text { Post- } \\
\text { intervention }\end{array}$ \\
\hline$\leq 5^{\text {th }}$ & 18.2 & 21.1 & 16.3 & 16.7 \\
\hline$>5^{\text {th }}$ and $<25^{\text {th }}$ & 40.9 & 21.1 & 29.7 & 23.4 \\
\hline$\geq 25^{\text {th }}$ and $\leq 75^{\text {th }}$ & 31.8 & 47.3 & 40.5 & 43.3 \\
\hline$>75^{\text {th }}$ and $<95^{\text {th }}$ & 9.1 & 10.5 & 13.5 & 13.3 \\
\hline$\geq 95^{\text {th }}$ & 0 & 0 & 0 & 3.3 \\
\hline \multicolumn{5}{|l|}{ PSNP } \\
\hline Height-for- & Boys $n=27$ & $n=20$ & Girls $n=32$ & $\mathrm{n}=21$ \\
\hline $\begin{array}{l}\text { age } \\
\text { Stunting }\end{array}$ & $\begin{array}{l}\% \text { Pre- } \\
\text { intervention }\end{array}$ & $\begin{array}{l}\% \text { Post- } \\
\text { intervention }\end{array}$ & $\begin{array}{l}\% \text { Pre- } \\
\text { intervention }\end{array}$ & $\begin{array}{l}\% \text { Post- } \\
\text { intervention }\end{array}$ \\
\hline$\leq 5^{\text {th }}$ & 22.2 & 15 & 25 & 33.3 \\
\hline$>5^{\text {th }}$ and $<25^{\text {th }}$ & 33.3 & 35 & 43.7 & 14.3 \\
\hline$\geq 25^{\text {th }}$ and $\leq 75^{\text {th }}$ & 40.7 & 35 & 25 & 38.1 \\
\hline$>75^{\text {th }}$ and $<95^{\text {th }}$ & 3.8 & 10 & 6.3 & 9.5 \\
\hline$\geq 95^{\text {th }}$ & 0 & 5 & 0 & 4.8 \\
\hline \multicolumn{5}{|l|}{ FRUIT } \\
\hline $\begin{array}{l}\text { Height-for- } \\
\text { age } \\
\text { Stunting }\end{array}$ & $\begin{array}{l}\text { Boys } \mathrm{n}=21 \\
\% \text { Pre- } \\
\text { intervention }\end{array}$ & $\begin{array}{l}\mathrm{n}=9 \\
\% \text { Post- } \\
\text { intervention }\end{array}$ & $\begin{array}{l}\text { Girls } \mathrm{n}=18 \\
\% \text { Pre- } \\
\text { intervention }\end{array}$ & $\begin{array}{l}n=13 \\
\% \text { Post- } \\
\text { intervention }\end{array}$ \\
\hline$\leq 5^{\text {th }}$ & 4.8 & 0 & 5.6 & 0 \\
\hline$>5^{\text {th }}$ and $<25^{\text {th }}$ & 28.6 & 22.2 & 33.3 & 15.4 \\
\hline$\geq 25^{\text {th }}$ and $\leq 75^{\text {th }}$ & 52.4 & 55.6 & 38.9 & 46.2 \\
\hline$>75^{\text {th }}$ and $<95^{\text {th }}$ & 9.5 & 22.2 & 16.7 & 38.4 \\
\hline$\geq 95^{\text {th }}$ & 4.8 & 0 & 5.6 & 0 \\
\hline
\end{tabular}

TABLE 4
Comparison of the BMI-for-age of the primary school children, pre- and postintervention

\begin{tabular}{|c|c|c|c|c|}
\hline \multicolumn{5}{|l|}{ VETKOEK } \\
\hline BMI-for-age & Boys $n=22$ & $n=18$ & Girls $n=37$ & $\mathrm{n}=29$ \\
\hline Wasting & $\begin{array}{l}\% \text { Pre- } \\
\text { intervention }\end{array}$ & $\begin{array}{l}\text { \% Post- } \\
\text { intervention }\end{array}$ & $\begin{array}{l}\text { \% Pre- } \\
\text { intervention }\end{array}$ & $\begin{array}{l}\text { \% Post- } \\
\text { intervention }\end{array}$ \\
\hline$\leq 5^{\text {th }}$ & 9.1 & 11.1 & 16.2 & 10.4 \\
\hline$>5^{\text {th }}$ and $<25^{\text {th }}$ & 36.4 & 33.3 & 32.4 & 31 \\
\hline$\geq 25^{\text {th }}$ and $\leq 85^{\text {th }}$ & 54.5 & 50 & 51.4 & 58.6 \\
\hline$>85^{\text {th }}$ and $<95^{\text {th }}$ & 0 & 5.6 & 0 & 0 \\
\hline$\geq 95^{\text {th }}$ & 0 & 0 & 0 & 0 \\
\hline \multicolumn{5}{|l|}{ PSNP } \\
\hline BMI-for-age & Boys $n=27$ & $n=19$ & Girls $n=32$ & $\mathrm{n}=21$ \\
\hline Wasting & $\begin{array}{l}\% \text { Pre- } \\
\text { intervention }\end{array}$ & $\begin{array}{l}\text { \% Post- } \\
\text { intervention }\end{array}$ & $\begin{array}{l}\text { \% Pre- } \\
\text { intervention }\end{array}$ & $\begin{array}{l}\text { \% Post- } \\
\text { intervention }\end{array}$ \\
\hline$\leq 5^{\text {th }}$ & 3.7 & 5.3 & 16.6 & 14.3 \\
\hline$>5^{\text {th }}$ and $<25^{\text {th }}$ & 29.6 & 31.5 & 43.8 & 38.1 \\
\hline$\geq 25^{\text {th }}$ and $\leq 85^{\text {th }}$ & 66.7 & 63.2 & 40.6 & 47.6 \\
\hline$>85^{\text {th }}$ and $<95^{\text {th }}$ & 0 & 0 & 0 & 0 \\
\hline$\geq 95^{\text {th }}$ & 0 & 0 & 0 & 0 \\
\hline \multicolumn{5}{|l|}{ FRUIT } \\
\hline BMI-for-age & Boys $n=21$ & $n=9$ & Girls $n=18$ & $n=13$ \\
\hline Wasting & $\begin{array}{l}\% \text { Pre- } \\
\text { intervention }\end{array}$ & $\begin{array}{l}\% \text { Post- } \\
\text { intervention }\end{array}$ & $\begin{array}{l}\% \text { Pre- } \\
\text { intervention }\end{array}$ & $\begin{array}{l}\% \text { Post- } \\
\text { intervention }\end{array}$ \\
\hline$\leq 5^{\text {th }}$ & 9.5 & 0 & 5.6 & 0 \\
\hline$>5^{\text {th }}$ and $<25^{\text {th }}$ & 9.5 & 12.5 & 22.2 & 30.8 \\
\hline$\geq 25^{\text {th }}$ and $\leq 85^{\text {th }}$ & 66.7 & 87.5 & 61.1 & 38.4 \\
\hline$>85^{\text {th }}$ and $<95^{\text {th }}$ & 9.5 & 0 & 0 & 15.4 \\
\hline$\geq 95^{\text {th }}$ & 4.8 & 0 & 11.1 & 15.4 \\
\hline
\end{tabular}

All the results were reported for boys and girls combined per group, except for the anthropometric results, because the NCHS growth charts are different for boys and girls.

\section{RESULTS}

Participants lost to follow-up study

During the study, the fewest children lost to the follow-up study 
occurred in the vetkoek group $(n=4)$; in the fruit group, five children did not participate in the follow-up measurements. Most of the children who were lost to the follow-up measurements were from the PSNP group ( $n=20)$, possibly because they did not benefit from this intervention. Because normal growth patterns of primary school children could confound the anthropometric results, it was decided to compare the biochemical measurements of the group who completed the study with those in the group that were lost to follow-up. In Table 1 it is shown that there were no statistically significant differences observed between the biochemical measurements and the weight, height or BMI variables of the three groups.

\section{Nutritional status}

A significant increase in weight and height occurred in all three study groups, which may be due to the normal growth process that took place in the children during the intervention. For this reason, only the NCHS nutritional status indices, described in the methodology, will be used for the interpretation of results.

Table 2 shows that underweight in the boys increased from $13.6 \%$ to $15.8 \%$ after the vetkoek intervention. In contrast, the girls showed a small improvement from $13.5 \%$ to $13.3 \%$. A similar trend was observed for the children at risk of being underweight in this group. The PSNP group showed results similar to those of the vetkoek intervention group. However, in the fruit group, both the boys and the girls showed a marked improvement after seven months. The children with high weight-for-age ( $>75$ th and $<95$ th percentile) in all three samples showed an increase in their status during this period except for the boys in the fruit sample, the latter having declined from $19 \%$ to $11.1 \%$.

Table 3 indicates that in the vetkoek group, 18.2\% of the boys and $16.3 \%$ of the girls were stunted at baseline, as shown in the height-for-age measurement at or below the 5 th percentile on the NCHS median. The intervention did not improve stunting in this sample. The PSNP group showed a decrease in the number of boys who were stunted (from $22.2 \%$ to $15 \%$ ) and an increase in the girls (from $25 \%$ to $33.3 \%$ ). The fruit group again showed an improvement in both boys and girls with regard

TABLE 5

Mean dietary intake compared to the EARs (24-hour recall), pre- and post-intervention

\begin{tabular}{|c|c|c|c|c|c|c|c|}
\hline \multirow[b]{2}{*}{ NUTRIENTS } & \multicolumn{3}{|c|}{ PRE-INTERVENTION } & \multicolumn{3}{|c|}{ POST-INTERVENTION } & \multirow[b]{2}{*}{$\begin{array}{l}\text { EARs } \\
\text { children } \\
\text { aged } \\
9-13 \\
\end{array}$} \\
\hline & $\begin{array}{c}\text { Vetkoek } \\
n=52\end{array}$ & $\begin{array}{l}\text { PSNP } \\
n=35\end{array}$ & $\begin{array}{l}\text { Fruit } \\
\mathrm{n}=27\end{array}$ & $\begin{array}{c}\text { Vetkoek } \\
n=55\end{array}$ & $\begin{array}{c}\text { PSNP } \\
n=38\end{array}$ & $\begin{array}{l}\text { Fruit } \\
\mathrm{n}=35\end{array}$ & \\
\hline Energy $\mathrm{kJ}$ & 4927 & 4815.2 & 5948.7 & $8415.33^{*}$ & $6388.3^{*}$ & $8444.22^{*}$ & 8368 \\
\hline $\begin{array}{l}\text { Total protein } \\
\text { (g) }\end{array}$ & 37.5 & 36.7 & 40.5 & $72.12^{*}$ & $48.5^{\star}$ & $59.81^{*}$ & 28 \\
\hline $\begin{array}{l}\text { Total Fat (g/ } \\
\text { day) }\end{array}$ & 36.04 & 30.62 & 40.06 & 51.42 & 44.06 & 39.41 & $25-35$ \\
\hline $\begin{array}{l}\text { Total Dietary } \\
\text { Fibre (g/day) }\end{array}$ & 12.81 & 12.94 & 14.56 & 17.18 & 17.16 & 14.95 & $25-31$ \\
\hline Calcium (mg) & 209.4 & 240 & 307.5 & $427.01^{\star} \#$ & 198.5 & 283.36 & $1300 \mathrm{Al}$ \\
\hline Iron (mg) & 4.88 & 4.86 & 5.5 & $21.09^{*} \#$ & $9.85^{*}$ & $11.78^{*}$ & 5.9 \\
\hline Zinc (mg) & 4.5 & 4.8 & 4.8 & $12.31^{\star} \#$ & $6.93^{*}$ & $8.38^{\star}$ & 7 \\
\hline
\end{tabular}

$\mathrm{g}=$ gram

${ }_{*}^{*}=$ significant increase from pre- to post-intervention, each group at $p<0.05$ $\mathrm{mg}=$ milligram

$\#=$ significant increase in vetkoek group compared to the other two groups at $p<0.05$ KJ = kilojoules

$\mathrm{EAR}=$ Estimated Average Requirements (Institute of Medicine, 2003)

$\mathrm{Al}=$ Adequate Intake to stunting. The children of normal height-for-age $(\geq 25$ th and $\leq 75$ th percentile) in all three samples increased except for the boys in the PSNP sample.

In the vetkoek sample the prevalence of wasting decreased in girls (from $16.2 \%$ to $10.4 \%$ ) but increased in the boys (from 9.1\% to $11 \%$ ). The PSNP group presented results similar to those of the vetkoek group for wasting. The fruit group showed a significant improvement in the prevalence of stunting in both boys and girls after the intervention. In the three groups little overweight (BMI-for-age $>85$ th and $\geq 95$ th percentile) was experienced. After the intervention, $5.6 \%$ of the boys in the vetkoek sample were reported to be overweight. The overweight girls in the fruit sample increased from $11.1 \%$ to $15.4 \%$.

In all the groups and within all the categories (with the exception of weight-for-age in the fruit group), the results showed an improvement in anthropometric indices. This improvement must, however, be interpreted with caution because the fact that there were five categories in each group meant that the number of children in each category was low, which influenced the power of the study.

\section{Dietary intake}

For the purpose of this article, total energy, protein, zinc, calcium and iron intakes reported will be discussed, since the focus of the measurement of nutritional status was intake of energy, zinc and iron. The majority of the children consumed a diet deficient in energy, zinc, iron and calcium, as can be seen in Table 5. It is further evident that the reported energy intake of the vetkoek, PSNP and fruit groups increased substantially $(\mathrm{p}<0.05)$, from $58.8 \%$ of the EAR for the vetkoek group, $57.7 \%$ for the PSNP group and $71 \%$ for the fruit group to $100.6 \%, 76.3 \%$ and $100.9 \%$ respectively.

The zinc intake increased in all three groups after the intervention. Before the intervention, the vetkoek group reported intakes of $64.2 \%$ of EAR, compared to $68.5 \%$ in the PSNP and fruit groups; after the intervention the vetkoek group reported intakes of $175.8 \%$ of EAR, compared to the PSNP and fruit groups' reported intakes of $99 \%$ and $119.7 \%$ of the EARs respectively. This indicated an increase at a significant level of $\mathrm{p}<0.05$ in the vetkoek, PSNP and fruit groups. It is clear that the vetkoek group, from being the group with the lowest intake of zinc, became the one with the highest intake, but all three groups showed a significant increase at $\mathrm{p}<0.05$.

The iron intake showed a similar increase in reported intake for all groups. The vetkoek group reported an increased intake from $82.7 \%$ to $357.5 \%$ of the EAR, the PSNP group reported intakes from $82.3 \%$ to $166.9 \%$ of the EAR and the fruit group reported intakes from $68.5 \%$ to $199.7 \%(p<0.05)$ of the EAR. A significant difference was also observed between the groups: the vetkoek group reported significantly greater intakes of iron $(p<0.05)$ than did the PSNP and fruit groups.

The total protein intake of the children in all three groups was substantially increased after the intervention, when compared to their intakes before the intervention $(\mathrm{p}<0.05)$. The vetkoek group was the only intervention that showed a statistically significant increase in reported calcium intake. Of the three groups, the vetkoek group reported the lowest calcium intake before the intervention (16\%). After the intervention, however, the vetkoek group reported an intake of $33 \%$ of EAR, the highest of the three groups. The vetkoek group showed a significant increase of reported calcium, zinc and iron $(\mathrm{p}<0.05)$ when compared to the PSNP and fruit groups.

\section{Biochemical measurements}

The haematological and biochemical data are summarised in Table 6. Only the respondents for whom data were available at the end of the study are included as post-intervention results, 
TABLE 6

Biochemical measurements of primary school children, pre- and post-intervention (Mahan \& Escott-Stump 2004)

\begin{tabular}{|c|c|c|c|c|c|c|c|}
\hline & & VETK & K GROUP & & GROUP & & GROUP \\
\hline & & $\begin{array}{l}\text { Pre-intervention } \\
n=53\end{array}$ & $\begin{array}{l}\text { Post-intervention } \\
n=45\end{array}$ & $\begin{array}{l}\text { Pre-intervention } \\
n=50\end{array}$ & $\begin{array}{l}\text { Post-intervention } \\
n=35\end{array}$ & $\begin{array}{l}\text { Pre-intervention } \\
\mathrm{n}=32\end{array}$ & $\begin{array}{l}\text { Post-intervention } \\
\mathrm{n}=\mathbf{2 1}\end{array}$ \\
\hline VARIABLE & NORMAL RANGE & MEAN (SD) & MEAN (SD) & MEAN (SD) & MEAN (SD) & MEAN (SD) & MEAN (SD) \\
\hline Vitamin A & $30-80 \mu \mathrm{g} / \mathrm{dl}$ & $28.74(6.16)$ & $27.23(7.19)$ & $28.71(7.66)$ & $29.21(7.58)^{\star}$ & $37.54(34.44)$ & $30.25(7.41)$ \\
\hline Zinc & $70-150 \mu \mathrm{g} / \mathrm{dl}$ & $88.56(14.78)$ & $86.04(17.35)$ & $83.17(12.39)$ & $83.12(14.93)$ & $85.44(10.67)$ & $90.87(19.37)^{*}$ \\
\hline Total Protein & $64-83 \mathrm{~g} / \mathrm{l}$ & 72.45 (11.62) & $76.10(6.77)$ & $75.05(12.15)$ & $77.71(7.41)$ & $76.13(10.24)$ & $75.41(6.46)^{\star}$ \\
\hline Iron & $9-31 \mu \mathrm{mol} / \mathrm{l}$ & $31.08(21.93)$ & $31.78(15.50)$ & $28.01(15.51)$ & $33.30(19.12)^{*}$ & $34.25(23.06)$ & $33.88(14.56)$ \\
\hline Transferrin & $2-4 \mathrm{~g} / \mathrm{l}$ & $2.99(0.60)$ & $3.09(0.51)$ & $3.17(0.51)$ & $3.17(0.51)$ & $3.21(0.61)$ & $3.25(0.54)^{*}$ \\
\hline Ferritin & $\begin{array}{l}12-150 \mu \mathrm{g} / \mathrm{l}(\mathrm{g}) \\
15-200 \mu \mathrm{g} / \mathrm{l}(\mathrm{b})\end{array}$ & $31.62(17.87)$ & $37.44(29.57)$ & $29.90(17.99)$ & $30.71(20.76)$ & $27.78(17.38)$ & $32.73(15.80)^{*}$ \\
\hline Albumin & $35-50 \mathrm{~g} / \mathrm{l}$ & $42.48(6.16)$ & $44.41(6.97)$ & $43.21(5.10)$ & $44.31(5.34)$ & $44.58(7.54)$ & $44.64(5.95)$ \\
\hline $\begin{array}{l}\text { Red blood cell } \\
\text { count }\end{array}$ & $4.0-5.4 \times 106 / \mu l$ & $4.62(0.58)$ & $4.67(0.32)$ & $4.55(0.33)$ & $4.67(0.32)^{\star}$ & $4.73(0.39)$ & $4.78(0.34)$ \\
\hline Haemoglobin & $12.0-14.0 \mathrm{~g} / \mathrm{dl}$ & $13.45(1.69)$ & $12.93(0.73)$ & $13.16(0.74)$ & $12.64(2.16)$ & $13.37(1.00)$ & $13.12(0.85)^{\star}$ \\
\hline Haematocrit & $36.0-44.0 \%$ & $39.83(4.69)$ & $38.551 .97)$ & $39.12(2.25)$ & $39.18(2.28)$ & $39.95(2.77)$ & 39.05 (2.59) \\
\hline $\begin{array}{l}\text { Mean red cell } \\
\text { volume }\end{array}$ & $77-91 \mathrm{fl}$ & $86.29(3.91)$ & $83.16(3.92)$ & $86.19(3.92)$ & $84.28(3.88)$ & $84.53(3.93)$ & 81.65 (2.59) \\
\hline White cell count & $4.5-13.5$ & $6.85(2.57)$ & $6.63(2.1)$ & $6.73(2.04)$ & $6.13(2.14)$ & $6.43(1.90)$ & $6.22(1.70)$ \\
\hline
\end{tabular}

${ }^{*}=$ significant difference from pre- to post-intervention, each group at $p \leq 0.05$ $g=$ girls

$b=$ boys

since the respondents lost to follow-up could not be included. The mean haematological and biochemical measurements for the respondents were similar for all three groups. The results further showed that in all three groups, most of the variables were within the normal ranges, except for the mean ferritin levels, which were marginal in all three groups, indicating a risk for iron depletion. Although the baseline survey (Napier 2006) found zinc levels to be marginal, in these respondents the zinc levels were normal in all three groups, but were closer to the minimum than the maximum parameter.

No statistically significant changes were observed in the vetkoek group, compared to vitamin A, serum iron and RBC in the PSNP group. The fruit group showed statistically significant increases in zinc, total protein, transferrin, ferritin and haemoglobin, thus indicating an improvement in both zinc and iron nutritional status. All three groups showed clinical changes but, while it is difficult to determine which one of the groups had the best results, it appears that the fruit group showed the greatest improvement. On further investigation, however, the ANOVA and post hoc analysis showed no statistical significance between the groups.

\section{School attendance}

The school register reflected the rate of absenteeism over the intervention period. Overall, the school attendance of the children taking part in the intervention initially decreased. During the second term, the absenteeism dropped by $37.9 \%$ in the vetkoek group, $21.3 \%$ in the PSNP group and $40.7 \%$ in the fruit group. This was the term during which the intervention started. Absenteeism did not increase in the following terms: far fewer children were absent during the last three terms than had been the case during the first term. No significant difference was found between the attendance ratios of the three groups.

\section{LIMITATIONS OF THE STUDY}

Results of this study should not be generalised, as the primary school children in this study are not a representative sample of the SA primary school population. Limitations should also be considered in the interpretation of the results. The first limitation of this study is related to the type and costs of the biochemical measurements. Calcium is a critical micronutrient during childhood, but the most accurate measurement of calcium is bone marrow analysis, which is too invasive and costly. The dietary intake levels, measured by both the 24-hour recall and the QFFQ, indicated low calcium intakes, and it is possible that the sample may also be calcium-deficient. The second limitation may lie in the power of the study. Of the 519 children in the school and their parents, only $160(30.8 \%)$ agreed to participate in the intervention trial. After dividing the volunteer respondents into three groups, namely the vetkoek, fruit and PSNP groups, the group sizes were reduced to 60,40 and 60 respectively. With a further $18 \%$ of the participants lost to follow-up (the majority of these from the PSNP group), the groups for the post-intervention tests were very small, with only 13 girls remaining in the fruit group. However, the statistically significant changes in certain biochemical measurements, as well as weight and height in al three groups, suggest that the power of the study may have been sufficient despite the fact that few statistically significant clinical results were obtained. The third limitation may be associated with the time period over which the school feeding programme was implemented. 150 school days interrupted by two school holidays (during which no school feeding took place) may have been too short to have a statistically significant impact on the nutritional status of the children. However, budgetary constraints made it impossible to continue with the intervention for longer than seven months.

\section{DISCUSSION}

Malnutrition remains a persistent problem amongst primary school children globally. This was confirmed in this sample of children in the assessment survey, where $28 \%$ stunting, $25 \%$ wasting and $12 \%$ underweight were found, indicating a chronic food shortage. Although various strategies have been adopted to address micronutrient deficiencies, these were still prevalent amongst this group of children. Of some concern may be that the children at risk of overweight (weight-for-height $>75$ th to 
$<95$ th percentile) in the three samples, with the exception of the boys in the fruit sample, increased. BMI-for-age is recommended for use in older children and adolescence and is an indicator of total body fat at the upper percentiles (WHO 1995). In the three samples the children that reported an increased BMI-for-age at $>85$ th to $<95$ th percentile level were the boys in the vetkoek sample and the girls in the fruit sample. It can be concluded that not one of the three feeding strategies caused excess body fat gain.

The three feeding strategies adopted for this study showed that the dietary intake levels in all three groups indicated statistically significant improvements for various macro- and micro-nutrients when compared to EARs. Although few statistically significant differences with regard to dietary intake patterns were observed between the groups, changes in biochemical variables and nutritional status indices were observed. Positive changes were observed in each of the groups, indicating that any food provision may have a positive impact on a malnourished child population. Any effect, no matter how small, may be beneficial to a malnourished child. This study proved that the nutritional intake and nutritional status of children can be improved in a controlled school feeding programme. This finding is supported by the results of a study in Kenya, where a well planned and nutritionally dense school feeding programme providing 33\% of the RDA of the children's energy needs and $88.8 \%$ of their RDA for protein resulted in an improvement in nutritional status. This study further found that $8 \%$ of the children taking part in this feeding scheme were malnourished, compared to $16.3 \%$ of the children not taking part (Musamali, Walingo \& Mbagaya 2007:5). A study by Reitsma et al. (1994:10) indicated that even after a school feeding scheme had been implemented in a primary school for two years prior to the study, malnutrition in the sample was still present and unacceptably high $(12 \%$ stunted, $18 \%$ underweight and $6 \%$ wasted), and recommended that the school feeding scheme should be continued in order to make an impact on the children's nutritional needs (Reitsma et al. 1994:12). School feeding programmes are a good strategy for addressing malnutrition amongst primary school children if they are monitored regularly. Commitment from the community and volunteer workers can assist in executing a well run and managed programme. The infrastructure, however, will have to be provided, with financial resources available to ensure a constant flow of ingredients or food items in order to provide a consistent supply of food to the children.

At the time of the baseline data collection, the fortification of maize meal had not been legislated in South Africa. Two months after the baseline survey it was legislated that all maize meal and wheat flour in South Africa be fortified with zinc oxide of 93.4 $\mathrm{g} / \mathrm{kg}$ and $35 \mathrm{mg}$ electrolytic iron per kilogram (DoH 2003). This study did not aim to measure the impact of the food fortification on nutritional status, but it can be concluded that fortification of both the maize meal and the wheat flour contributed to the improved nutritional status of all three groups. Although no statistically significant differences occurred in micronutrient status amongst the three groups, the reported dietary zinc and iron intakes increased in all three groups. This is possibly due to the added micronutrients in the fortified maize and wheat flour.

The children that were lost to follow-up were mainly from the PSNP sample $(n=20)$. Children in this sample benefited from the PSNP before the intervention, and although this sample was compared to the other two samples, nothing new was presented. It is likely that the children still received the PSNP but that the parents and children did not see the need to come for follow-up measurements as they were not receiving anything out of the ordinary and thus became lost to the study.

The low weight gain indicated in this study is in line with the results of a review completed in 2007, where it was found that in 18 school feeding studies, those completed in low income countries showed weight gain of $0.39 \mathrm{~kg}$ over a period of 19 months and $0.71 \mathrm{~kg}$ over a period of 11.3 months. School attendance was higher in the experimental groups of these studies as well as in the current study (Kristjansson et al. 2007). Recently, Greenhalgh, Kristjansson and Robinson (2007:859) concluded that process data from some of the trials reviewed by the researchers suggested that in situations of absolute poverty, even severely malnourished children may not benefit from school feeding, as feeding at home may not support the nutritional needs of the children. It is suggested, however, that further research be conducted to address this theory.

\section{CONCLUSION}

This was the first time that three feeding strategies were conducted amongst primary school children in the Vaal Region, as this region is usually included in the Gauteng results for national census and other surveys. The results of this study clearly indicate that it does not matter whether the vetkoek, PSNP or fruit approach is followed. It does, however, appear that the fruit group obtained significantly improved zinc and iron status, compared to improved serum vitamin A and iron levels in the PSNP group. Furthermore, the fortification of maize meal and wheat flour may have played a synergistic role in improving the nutritional status of the total group of children in this sample. Strategies can thus be implemented simultaneously in the fight against child malnutrition. The results of this study showed that the provision of fruit as a school feeding strategy may be effective in fighting malnutrition. Moreover, it is both affordable and easy to implement.

\section{RECOMMENDATIONS}

Further research is recommended to measure the impact of a variety of food-based approaches to determine the most costeffective, sustainable and nutritious strategy in addressing malnutrition amongst primary school children in poor urban areas similar to this informal settlement. A combination of strategies may be needed to ensure adequate nutrient intakes for all South Africans. As a result of the high prevalence of HIV/ AIDS in South Africa, future school-based nutrition research should include measuring the presence of HIV/AIDS.

\section{REFERENCES}

Department of Health, 2003, Foodstuffs, Cosmetics and Disinfectants Act, 1972 (Act no. 54 of 1972): Regulations relating to the fortification of certain foodstuffs, viewed 1 June 2006, from http://www.doh.gov.za.

Food and Agriculture Organization of the United Nations, 1998, The right to food in theory and practice, United Nations, Rome.

Gauteng Department of Health, 1997, Gauteng PSNP policy document, Government Printers, Pretoria.

Gibson, R.S., 2005, Principles of nutritional assessment, 2nd edn., Oxford University Press, New York.

Greenhalgh, T., Kristjansson, E. \& Robinson, V., 2007, 'Realist review to understand the efficacy of school feeding programmes', British Medical Journal 335, 858-861.

IOM, 2003, Dietary reference intakes (DRI's), viewed 7 March 2005, from http:/www.iom.edu/object.File/Master/21/372/0.pdf.

Joubert, G. \& Ehrlich, R., 2008, Epidemiology: A research manual for South Africa, 2nd edn., Oxford University Press, South Africa.

Kearney, J.E., 2006, 'Development of a novel breakfast food product for primary school children in an informal settlement', MTech dissertation, Vaal University of Technology.

Kristjansson, E.A., Robinson, V., Petticrew, M., Macdonnald, B., Krasevec, J., Janzen, L. et al., 2007, 'School feeding for improving the physical and psychosocial health of disadvantaged students', Cochrane Database of Systematic Reviews, Issue 1, Art. No.: CD004676. DOI: 10.1002/14651858. CD004676.pub2.

Labadarios, D., 2000, The National Food Consumption Survey (NFCS): Children aged 1-9 years, South Africa, 1999, University of Stellenbosch, Stellenbosch. 
Levitsky, D.A., 2005, 'The future of school feeding programs', Food and Nutrition Bulletin 26(2), S268-S278.

Macintyre, U., 1998, 'Dietary intakes of Africans in transition in the North-West province', PhD dissertation, Potchefstroom University for Christian Higher Education.

Mahan, L.K. \& Escott-Stump, S., 2004, 'A guide to the use of laboratory data in nutritional assessment and monitoring', in Krause's Food, Nutrition, E Diet Therapy, 11th edn., Saunders, Philadelphia.

McIlrath, L. \& Slabbert, T., 2003, Sedibeng Economic Regeneration Summit, Sedibeng Municipality, Vanderbijlpark.

Musamali, B., Walingo, M.K. \& Mbagaya, G.M., 2007, 'Impact of school lunch programmes on nutritional status of children in Vihiga district, western Kenya', African Journal of Food Agriculture Nutrition and Development 7(6), 5-6.

Napier, C.E., 2006, 'Evaluation of a feeding programme in addressing malnutrition in a primary school', DTech thesis, Vaal University of Technology.

Oldewage-Theron, W.H., Dicks, E.G. \& Napier, C.E., 2006, 'Poverty, household food insecurity and nutrition: Coping strategies in an informal settlement in the Vaal Triangle, South Africa', Public Health 120, 795-804.

Oldewage-Theron, W.H., Dicks, E.G., Napier, C.E. \& Rutengwe, R., 2005, 'Situation analysis of an informal settlement in the Vaal Triangle', Development Southern Africa 22(1), 13-26.
Reitsma, G.M., Vorster, H.H., Venter, C.S., Labadarios, D., De Ridder, J.H. \& Louw, M.E.J., 1994, 'A school feeding scheme did not improve nutritional status of a group of black children', South African Journal of Clinical Nutrition 7(1), 10 18

SAVACG, 1995, Children aged 6 to 71 months in South Africa, 1994 : Their anthropometric, vitamin $A$, iron and immunisation coverage status, p. 335, Isando.

UNICEF, 1998, The state of the world's children, United Nations New York.

UNICEF, 2001, The state of the world's children, United Nations, New York

Vorster, H.H., Oosthuizen, J.C., Jerling, W., Veldman, F.J. \& Burger, H.M., 1997, The nutritional status of South Africans: A review of the literature from 1995-1996, Health Systems Trust, Durban

Vorster, H.H., Jerling, J.C., Steyn, K., Badenhorst, C.J., Slazus, W., Venter, C.S. et al., 1998, 'Plasma fibrinogen of black South Africans: The BRISK study', Public Health Nutrition 1(3), 169176.

World Health Organization, 1995, 'Physical status: The use and interpretation of anthropometry', Report of a WHO Expert Committee, Technical Report Series No. 854, Switzerland. 